
\title{
$\angle S$ Research Square \\ Distribution and risk assessment of heavy metals in soil in a commonly used mining area
}

\section{Lei Xu ( $\nabla 18765231629 @ 163 . c o m)$}

1)Institute of Applied Ecology, Chinese Academy of Sciences, China;2)University of Chinese Academy Sciences, China

\section{Huiping Dai}

Shaanxi University of Technology, China

\section{Lidia Skuza}

University of Szczecin, Poland

\section{Shuhe Wei}

Institute of Applied Ecology, Chinese Academy of Sciences, China https://orcid.org/0000-0001-69834394

\section{Research Article}

Keywords: Heavy metal, Distribution characteristic, Mining area, Health risk, Ecological risk

Posted Date: September 3rd, 2021

DOl: https://doi.org/10.21203/rs.3.rs-866273/v1

License: (c) (i) This work is licensed under a Creative Commons Attribution 4.0 International License.

Read Full License 
1 Distribution and risk assessment of heavy metals in soil in a commonly used mining

2 area

3 Lei $\mathrm{Xu}^{\mathrm{a}, \mathrm{d}}$, Huiping Dai ${ }^{\mathrm{b}, *}$, Lidia Skuza ${ }^{\mathrm{c}}$, Shuhe $\mathrm{Wei}^{\mathrm{a},{ }^{*}}$

4

$5{ }^{\text {a }}$ Key Laboratory of Pollution Ecology and Environment Engineering, Institute of 6 Applied Ecology, Chinese Academy of Sciences, Shenyang 110016, China;

$7 \quad{ }^{\mathrm{b}}$ College of Biological Science \& Engineering, Shaanxi Province Key Laboratory of

8 Bio-resources, Shaanxi University of Technology, Hanzhong 723001, China;

$9{ }^{\mathrm{c}}$ Institute of Biology, Centre for Molecular Biology and Biotechnology, University of Szczecin, Szczecin 71-415, Poland;

${ }^{\mathrm{d}}$ University of Chinese Academy of Sciences, Beijing 100039, China.

*Corresponding author. Tel: +86-24-83970382; Fax: +86-24-83970382

Email address: daihp72@snut.edu.cn (H. Dai); shuhewqei@iae.ac.cn (S. Wei) 


\section{Abstract}

This study investigated the spatial, vertical and fraction distribution, multivariate statistical analysis, as well as assessed pollution levels and health risks posed by heavy metals at the Wenshan mining area. There were 6 sampling points at the site, from which a total of 32 samples were collected. The eastern and south-eastern parts of the site were heavily polluted, while the western and north-western parts were less contaminated. As pollution was particularly severe in the topsoil, with the mean value of $503.31 \mathrm{mg} \mathrm{kg}^{-1}$ being more than 25 -fold higher than the risk screening value. As content in all layers was greater than the standard risk screening value in the three typical profiles. The proportion of various $\mathrm{Ni}, \mathrm{Cu}$ and $\mathrm{As}$ fractions changed slightly with depth at all three sampling points, and the residual fraction percentage accounted for more or nearly $80 \%$ of the total concentration. In addition, a significantly negative correlation $(\mathrm{p}<0.05)$ was detected between $\mathrm{Ni}$ and $\mathrm{As}(-0.85)$, indicating a different source of these two elements. Principal component analysis demonstrated that two PCs, i.e. PC1, attributed to human activities, e.g. mining activities and transport, and PC2, defined as natural sources, were responsible for $80.632 \%$ of the total variance. As posed severe ecological and unacceptable health risks, i.e. non-carcinogenic and carcinogenic risks both for adults and children. Therefore, a comprehensive understanding of the characteristics of mining pollutants and improved emission management in the mining process are essential to protect the environment and health of local residents.

Keywords: Heavy metal; Distribution characteristic; Mining area; Health risk;

Ecological risk 


\section{Introduction}

The problem of soil contamination with heavy metals has become an increasing global concern (Xu et al., 2021). Sources of heavy metals in soil mainly include natural and anthropogenic aspects, and the latter mainly involve mining, smelting and other industrial activities (Ran et al., 2021). Among these, mining activities are known to be one of the main sources of heavy metal pollution (Liu et al., 2014). Mining activities have provided us humans with a large amount of materials and energy, while they have also caused enormous environmental pollution from tailings and mining wastewater (Wu et al., 2021). This issue is an urgent problem all over the world, and it deserves special attention in China. Heavy metal pollution is characterized by long duration, concealment, accumulation and irreversibility (Stylianou et al., 2020). This not only poses a threat to the soil and water environment, but also affects the quality of crops, etc., and causes risks to human health through the food chain ( $\mathrm{Li}$ et al., 2020a; Ran et al., 2021).

Remediation of contaminated soil requires an enormous amount of time and materials, thus it was necessary to understand the impact of heavy metals on the local environmental system, i.e. heavy metal distribution in the soil, environmental and human health risks. Previous studies concerning heavy metal pollution in soil have mainly focused on their spatial distribution, environmental and health risk assessments and the analysis of heavy metal sources (Wang et al., 2021). Systematic studies of the spatial distribution of soil heavy metals are essential for pollution assessment and risk control (Cui et al., 2021). Typically, a geographic information 
system (GIS) and Surfer software can be used to characterize the spatial distribution of heavy metals (Chai et al., 2021; Sun et al., 2019). Numerous indices, such as the geo-accumulation index (Igeo) (Negahban et al., 2021), pollution index (PI) (Yang et al., 2021), Nemerow integrated pollution index (NIPI) (Guan et al., 2020) or enrichment factor (EF) (Yu et al., 2021) were applied to evaluate the ecological contamination risk. There are also many indices for health risk assessment, and a model introduced by USEPA, which includes the hazard index (HI) and cancer risk (CR) is one of the most widely applied to evaluate non-carcinogenic and carcinogenic risks to human body caused by pollution (Huang et al., 2021). Geostatistical models based on geographic information systems (GIS) (Yu et al., 2021) and multivariate statistical methods, e.g. principal component analysis (PCA), cluster analysis (CA) and correlation analysis are often used to qualitatively identify the origin of elements in soil (Liu et al., 2021). In addition, quantitative methods mostly involve receptor models, such as the chemical mass balance (CMB) model (Jiang et al., 2017) or positive matrix factorization (PMF), etc. (Wang et al., 2021).

Wenshan is an extremely rich area of high-grade underground mineral resources. There is a variety of black, nonferrous, rare and precious metals as well as non-metallic minerals, and the resources of various minerals in this region rank among the top of the country. The Wenshan $\mathrm{Pb}-\mathrm{Zn}$ mine is located in the Southeast Yunnan fold belt of the South China fold system, which is a medium-sized mining area with arsenic. An open-pit mining method was adopted there at the early stages of mine design, and an underground mining method was adopted at a later stage. The 
study area is a carbonate type lead-zinc ore body, and granite is the key mineralization factor.

It is commonly known that the mining process has a great impact on the surrounding environment. However, there are few studies that have comprehensively analyzed pollution distribution and ecological and health risks for local residents in the mining area. Moreover, numerous studies have indicated that it is necessary to analyze the fraction of heavy metals, due to the availability of heavy metals were close to the influence of their availability (Zhong et al., 2020). Not only the total concentration of heavy metals, but also heavy metal fractions are essential to determine their ecological and health risks (Cui et al., 2021). However, previous studies on heavy metal distribution mainly focused on the spatial and/or vertical distribution, fewer studies concerned their fraction distribution and variability with depth (Masri et al., 2021). In the present study, the Wenshan site was selected to systematically and comprehensively analyze the distribution of heavy metals, i.e. spatial distribution, vertical distribution and fraction distribution in the mining area. Multivariate statistical analysis was used to investigate the correlation and sources of heavy metals, as well as ecological and health risks for both adults and children. Therefore, the study aimed to (1) comprehensively analyze distribution characteristics (including spatial, vertical, and fraction distributions) of heavy metals; (2) analyze the correlation of heavy metals and their possible sources; (3) determine the Igeo, PI and NIPI values of ecological risks and the $\mathrm{HI}$ and $\mathrm{CR}$ values of health risks for both adults and children. This work can provide certain theoretical support and practical 
basis for more comprehensive research on the distribution of heavy metals in mines, as well as ecological and health risks associated with them, resulting in a better

117 protection of the environment and human health.

\section{Materials and Methods}

\subsection{Study area, sampling and analysis}

\subsubsection{Study area}

Wenshan Prefecture is located in the southeast of the Yunnan-Guizhou Plateau, between $103^{\circ} 35^{\prime}-106^{\circ} 12^{\prime}$ east longitude and $22^{\circ} 40^{\prime}-24^{\circ} 48^{\prime}$ north latitude, the average altitude is between 1000 and 1800 meters. The climate of Wenshan is a tropical monsoon climate, with an average annual temperature of $19^{\circ} \mathrm{C}$ and an annual rainfall of $779 \mathrm{~mm}$. As for the sampling points, the Wenshan mining site occupies 50 acres, with 14 years of operation time. The terrain of the site is mainly mountainous, soil type is yellow soil developed by granite with partial sand. locations and cases.

\subsubsection{Soil sampling and chemical analysis}

Six sampling points were reasonably set out on the basis of preliminary experiments and sufficient background studies (Fig. 1). The sampling depth of sample points $\mathrm{Y} 1$ and $\mathrm{Y} 4$ was $4 \mathrm{~m}, \mathrm{Y} 2$ and $\mathrm{Y} 6-2.5 \mathrm{~m}, \mathrm{Y} 5-3 \mathrm{~m}$ and $\mathrm{Y} 3-1 \mathrm{~m}$. One sample 
was collected every $0.5 \mathrm{~m}$ in the upper $3 \mathrm{~m}$, and one sample was collected in the lower $1 \mathrm{~m}$. Thus, there were 7 samples collected at points $\mathrm{Y} 1$ and Y4, 5 samples at points $\mathrm{Y} 2$ and $\mathrm{Y} 6,6$ samples at point $\mathrm{Y} 5$ and 2 samples at point $\mathrm{Y} 3$, thus a total of 32 samples was collected. All soil samples were collected in plastic zip-lock bags and transported immediately to the laboratory. All soil samples were dried at room temperature, ground and sieved through a $0.15-\mathrm{mm}$ nylon sieve, and subsequently stored in plastic zip-lock bags.

For the determination of total metal concentrations, the soil samples were digested with $\mathrm{HCl}-\mathrm{HNO}_{3}-\mathrm{HF}-\mathrm{HClO}_{4}$ and then assayed using inductively-coupled plasma optical emission spectroscopy (ICP-OES, Agilent 5100 SVDV ICP-OES, America Agilent Technologies). National first-level standard materials for soil, i.e. GBW07405 (obtained from the National Standard Detection Research Center, Beijing, China) and reagent blanks, were used to ensure the accuracy of sample digestion procedure and subsequent determinations with respect to the quality assurance and quality control (QA/QC) (Kong et al., 2021). With respect to the recovery of heavy metals, i.e. Ni, Pb, $\mathrm{Cd}, \mathrm{Cu}$ and $\mathrm{As}$, the values ranged from $96.8 \%$ to $101.7 \%$, indicating that digestion and determination processes of heavy metals in soil were reliable.

A modified three-step Community Bureau of Reference (BCR) method was used to sequentially extract different fractions of heavy metals from the soil (Zhang et al., 2020; Xiao etal., 2019; Ure et al., 1993). The prepared solution was added to a 50-ml centrifuge tube, after thorough mixing with the previously added $1 \mathrm{~g}$ of the tested soil; the following fractions were obtained: acid-soluble, reducible and oxidizable heavy 
metal fractions (Zhang et al., 2020). The remaining residue was digested as in the total concentration measurement method $\left(\mathrm{HCl}-\mathrm{HNO}_{3}-\mathrm{HF}-\mathrm{HClO}_{4}\right)$ to obtain the

residual fraction of heavy metals, and subsequently all heavy metal fractions were determined using ICP-OES. All samples were processed in triplicate and the error between the three repetitions was within $5 \%$, indicating reliability of the results.

\subsection{Contamination and risk assessment}

\subsubsection{Geo-accumulation index}

The geo-accumulation $\left(\mathrm{I}_{\mathrm{geo}}\right)$ index was applied to assess soil contamination by comparing the current concentration with geochemical background values of these elements (Hou et al., 2019). The equation was as follows:

$I_{\text {geo }}=\log _{2} \frac{\mathrm{C}_{i}}{1.5 B_{i}}$

where $C_{i}$ is the measured concentration of element $i$ in soil, $B_{i}$ is the geochemical background value of element $\mathrm{i}$ obtained from the China National Environmental Monitoring Centre (CNEMC); the background values of $\mathrm{Ni}, \mathrm{Pb}, \mathrm{Cd}, \mathrm{Cu}$ and $\mathrm{As}$ in Yunnan province were $42.5,40.6,0.218,46.3$ and $18.4 \mathrm{mg} \mathrm{kg}^{-1}$, respectively (CNEMC, 1990). Seven levels were distinguished based on the $\mathrm{I}_{\text {geo }}$ value: $<0,0-1,1-2$, $2-3,3-4,4-5, \geq 5$, representing uncontaminated, uncontaminated to moderately contaminated, moderately contaminated, moderately to heavily contaminated, heavily contaminated, heavily to extremely contaminated and extremely contaminated, respectively (Liu et al., 2021). 
The pollution index (PI) was used to evaluate the pollution risk of a single factor,

while the Nemerow integrated pollution index (NIPI) was applied to comprehensively represent the risk of contamination with multiple heavy metals (Nemerow, 1974), taking into account the average and highest values (Chai et al., 2021). The formulas for calculating the PI and NIPI are as follows:

$$
P I=\frac{C_{i}}{S_{i}}
$$

$$
\text { where PI is the pollution index of a single element (i); } C_{i} \text { is the concentration of a }
$$

single element (i); $S_{i}$ is the threshold concentration of element $\mathrm{i}$ (Table 1).

$$
N I P I=\sqrt{\frac{P I_{\text {max }}^{2}+P I_{\text {ave }}{ }^{2}}{2}}
$$

where NIPI is the composite pollution index in soil; $\mathrm{PI}_{\max }$ is the maximum PI value of all elements; $\mathrm{PI}_{\mathrm{ave}}$ is the average PI value for all elements. There were five levels distinguished based on the PI and NIPI values: $<0.7,0.7-1,1-2,2-3, \geq 3$, representing no pollution, precautionary pollution, low pollution, moderate pollution and severe pollution, respectively (Liu et al., 2021).

\subsection{Health risk assessment}

The hazard index $(\mathrm{HI})$ and carcinogenic risk $(\mathrm{CR})$ values were used to evaluate the non-carcinogenic and carcinogenic risks based on the USEPA health risk assessment model. Both children (1-17 years old) and adults (over 18 years old) were considered, as well as three exposure routes, i.e. ingestion, dermal contact and inhalation were included in this model for health risk assessment. Average daily doses (ADDs), 
including ingestion $\left(\mathrm{ADD}_{\text {ing }}\right)$, dermal contact $\left(\mathrm{ADD}_{\text {derm }}\right)$ and inhalation $\left(\mathrm{ADD}_{\text {inh }}\right)$ were calculated for both children and adults using formulas (4-6) from the Exposure Factors Handbook proposed by the United States Environmental Protection Agency

207 (USEPA, 1989, 1997, 2001):

$208 A D D_{\text {ing }}=\frac{C_{i} \times \operatorname{Ing} R \times E F \times E D}{\mathrm{BW} \times \mathrm{AT} \times 10^{6}}$

$209 A D D_{\text {derm }}=\frac{C_{i} \times S A \times A F \times A B S \times E F \times E D}{\mathrm{BW} \times \mathrm{AT} \times 10^{6}}$

$A D D_{\text {inh }}=\frac{C_{i} \times A P M \times I n h R \times E F \times E D}{\mathrm{BW} \times \mathrm{AT} \times 10^{6}}$

211 where $\mathrm{C}_{\mathrm{i}}$ is pollutant concentration in soil $\left(\mathrm{mg} \mathrm{kg}^{-1}\right)$; IngR is the ingestion rate per

212 time unit $\left(\mathrm{mg} \mathrm{d}^{-1}\right)$; EF and ED represent exposure frequency (d year $\left.{ }^{-1}\right)$ and exposure

213 duration (year), respectively; BW is body weight $(\mathrm{kg})$ and AT is the average time of 214 no cancer risk (d); SA and AF represent exposed skin area $\left(\mathrm{cm}^{2}\right)$ and skin adherence 215 factor $\left[\mathrm{mg}\left(\mathrm{cm}^{2} \cdot \mathrm{d}\right)^{-1}\right]$, respectively; ABS is the dermal absorption factor; APM is 216 ambient particulate matter $\left(\mathrm{mg} \mathrm{m}^{-3}\right)$; InhR means soil inhalation rate $\left(\mathrm{m}^{3} \mathrm{~d}^{-1}\right)$ (Liu et 217 al., 2021; Wang et al., 2020).

218 The hazard quotient (HQ) was used to evaluate non-carcinogenic risks and the 219 formula was as follows (USEPA, 1989):

$220 H Q=\frac{\mathrm{ADD}}{\mathrm{RfD}}$

221 where RfD is the reference dose per day of specific heavy metal for each route of 222 exposure $\left[\mathrm{mg}(\mathrm{kg} \cdot \mathrm{d})^{-1}\right]$.

223 The potential non-carcinogenic risk of multiple heavy metals was evaluated based 224 on the hazard index (HI) (USEPA, 1989), according to the following equation:

$225 \quad H I=\sum_{i=1}^{n} H Q_{i}=\sum_{i=1}^{n} \frac{A D D_{i}}{R f D_{i}}$ 
$\mathrm{HQ}>1$ or $\mathrm{HI}>1$ represent a significant potential non-carcinogenic risk for humans; otherwise no significant risk occurs.

The possibility of developing cancer for a person when exposed to multiple heavy metals was calculated based on the $\mathrm{CR}$ value according to the following equation (USEPA, 1989):

$C R=A D D \times S F$

where SF is the carcinogenic slope factor of heavy metals for each exposure route. Three carcinogenic risk levels were listed based on the $\mathrm{CR}$ values: $\mathrm{CR}<1 \times 10^{-6}$ indicates no carcinogenic risk; $1 \times 10^{-6}<\mathrm{CR}<1 \times 10^{-4}$ indicates a generally acceptable risk; $\mathrm{CR}>1 \times 10^{-4}$ indicates an unacceptable risk (Liu et al., 2021).

\subsection{Data analysis}

The data were organized and analyzed using Microsoft Office Excel 2010 (Microsoft Corporation, Redmond, WA, USA). Surfer 11.0 (Golden Software, Colorado, USA) was used to create figures heavy metal spatial distribution of, and Origin 9.0 (OriginLab, Northampton, MA, USA) and Microsoft Office Excel 2010 were used for vertical and fraction distribution of heavy metals. In addition, SPSS 16.0 (SPSS Inc., Chicago, IL, USA) was applied to analyze the correlation coefficient and principal component analysis (PCA) of heavy metals. Pearson's correlation matrix was created using the R package corrplot (Version 4.0.3).

\section{Results and Discussion}

\subsection{Concentration of heavy metals in soil}




\subsubsection{Descriptive statistics of heavy metal concentrations in the topsoil}

The concentrations of heavy metals were influenced by many factors, including the distribution and release of pollution sources, the characteristic of heavy metals and soil, as well as environmental conditions (Liu et al., 2020). The descriptive statistical concentrations of five heavy metals in the topsoil at the Wenshan site are summarized in Table 1. In general, as pollution in the topsoil was particularly severe, the mean As concentration of $503.31 \mathrm{mg} \mathrm{kg}^{-1}$ was more than 25-fold higher compared to the risk screening value $\left(20 \mathrm{mg} \mathrm{kg}^{-1}\right)$, while the maximum value $\left(713.36 \mathrm{mg} \mathrm{kg}^{-1}\right)$ exceeded the risk screening value more than 35-fold (GB36600-2018, MEE, 2018). As a type of guest metal, arsenic is found in many kinds of ores (Zhong et al., 2020). The results indicated that the ecological environment and human health could be adversely affected due to the severely exceeded screening value (Cheng et al., 2020). The concentrations of $\mathrm{Ni}, \mathrm{Pb}, \mathrm{Cd}$ and $\mathrm{Cu}$ were $26.26 \mathrm{mg} \mathrm{kg}^{-1}, 70.45 \mathrm{mg} \mathrm{kg}{ }^{-1}, 7.04 \mathrm{mg}$ $\mathrm{kg}^{-1}$ and $292.24 \mathrm{mg} \mathrm{kg}^{-1}$, respectively, which were all below the risk screening values. Spatial variability was influenced by natural or extrinsic factors (Zhao et al., 2010). Natural variability was mainly related to the weathering of soil parent materials, while the extrinsic factors included human activities, e.g. mining (Li et al., 2017). The coefficient of variation (CV), representing the variability of heavy metal concentrations, was defined as the ratio of standard deviation (SD) to the average of an element (Yu et al., 2021). High CV for heavy metals indicated that their concentrations were affected by the presence of the mine (Cheng et al., 2020). Three levels of the $\mathrm{CV}$ were distinguished, i.e. low variation, moderate variation and high 
variation, with values of $\leq 16 \%, 16 \%<\mathrm{CV} \leq 36 \%$ and $\mathrm{CV}>36 \%$, respectively (Chai et al., 2021). As shown in Table 1, the CV values of $\mathrm{Ni}, \mathrm{Pb}, \mathrm{Cd}, \mathrm{Cu}$ and As were $54.03 \%$, $20.13 \%, 43.86 \%, 62.07 \%$ and $34.15 \%$, respectively. Among them, $\mathrm{Ni}, \mathrm{Cd}$ and $\mathrm{Cu}$ values constituted more than $36 \%$ of the critical value for high variation, indicating a strong influence of extrinsic factors, such as mining on element distribution.

Table 1 Heavy metal concentrations in the topsoil at the Wenshan site

\subsubsection{Spatial distribution of heavy metals}

The spatial distribution of heavy metals in soil is the basis for the evaluation of pollution risk and decision-making, which was also essential for the understanding the environmental behavior of heavy metals (Liu et al., 2020; Niazi et al., 2011). The map of heavy metal distribution in the topsoil was generated in Surfer 11.0 using the Kriging interpolation method (Fig. 2). It can be seen that the spatial distribution of heavy metals strongly varied. Ran et al. (2021) pointed out that the spatial distribution of metal in soil was controlled by several factors, including original content of metalloids in the parent materials and rocks, active pedogenesis and various anthropogenic factors. The distribution of $\mathrm{Ni}$ was quite different from other heavy metals, which indicated that $\mathrm{Ni}$ could have originated from different sources than other metals (Fig. 5); Ni content was higher in the southeast of the site, where point Y5 was located, and lower in the northwest in the vicinity of points Y1, Y2 and Y3, but they were still higher than the risk screening value (GB36600-2018). The 
distribution of $\mathrm{Cd}$ and $\mathrm{Pb}$ was relatively similar, with a higher content in the

294 southwest of the site where point Y6 was located, and a lower content in the 295 northwest near point Y4, which could be related to transportation. $\mathrm{Cu}$ content was 296 higher in the southwest of the site where point Y3 was established, and it gradually

decreased toward the northeast, but none of them exceed the risk screening value. As content strongly exceeded the standard in all the samples collected from the site. Among them, the highest concentrations were recorded in points $\mathrm{Y} 2$ and $\mathrm{Y} 6$ in the west and southwest of the site, and they exceeded the risk screening value by more than 30 -fold. As content at point Y5 in the west of the site, with a low pollution degree, still exceeded the risk value nearly 10-fold (GB36600-2018). Overall, the eastern and south-eastern parts of the site were highly polluted, while the western and north-western parts were less polluted.

Fig. 2. Spatial maps showing the distribution of heavy metals in the topsoil of the Wenzhou mining site.

\subsubsection{Vertical distribution of heavy metals}

The mining process usually lasted for decades and the tailing piled up were even perennial, thus it was necessary to collect soil samples from a well-developed profile to study downward migration and vertical distribution of heavy metals ( $\mathrm{Li}$ et al., 2009). Fig. 3 shows three typical profiles (point Y1, Y4 and Y5) collected to demonstrate the vertical distribution of heavy metals. As content in all layers was 
greater than the standard risk screening value in the three typical profiles. This was mainly related to the fact that the mine was associated with arsenic. Especially in point Y1, As concentration in deeper layers (L6 and L7 - $1412.33 \mathrm{mg} \mathrm{kg}^{-1}$ and $1202.49 \mathrm{mg} \mathrm{kg}^{-1}$, respectively) was higher than in lower ones (L1 and L2 - 550.11 mg - $1305.99 \mathrm{mg} \mathrm{kg}^{-1}$ and $1345.17 \mathrm{mg} \mathrm{kg}^{-1}$, respectively) was the highest at point $\mathrm{Y} 4 . \mathrm{In}$ addition, no significant changes with increasing depth were recorded. Li et al. (2020b) reported that the content of certain elements changed little with increasing depth. Moreover, the concentrations in deeper layers were higher than in the shallow soil (Huang et al., 2009). Unlike the previous study, the present results were more likely caused by natural factors. In addition, the contents of $\mathrm{Ni}, \mathrm{Pb}, \mathrm{Cd}$ and $\mathrm{Cu}$ were all below the risk screening values, indicating that there would be no major environmental impact in the short term. It should be noted that $\mathrm{Ni}, \mathrm{Pb}$ and $\mathrm{Cd}$ concentrations changed only slightly with depth. This might be attributed to the persistent pollution and leaching (Li et al., 2009).

Fig. 3. Vertical distribution of soil heavy metal concentrations at different sampling points (Y1(a), Y4(b) and Y5(c)).

\subsubsection{Fraction distribution of heavy metals}

Total concentration of heavy metals was important for the assessment of pollution degree, but fraction distribution of heavy metals, especially the proportion of active 
fraction was directly related to the ecological environment and human health, which also requires special attention (Li et al., 2009). Sampling points Y1, Y4 and Y5 were selected to test fraction variation with depth using the BCR sequence (Fig. 4). At point Y1, fraction variation of almost all heavy metals changed little with depth. What is more, the residual (F4) fraction constituted a high percentage (close to $70 \%$ ), and the acid soluble (F1) fraction constituted a low proportion in case of all types of heavy metals. As shown in Fig. 4(a), the F1 fraction of all heavy metals was lower than 10\%, and the percentages of $\mathrm{Pb}, \mathrm{Cd}$ and $\mathrm{Cu}$ were lower than $1 \%$. The results were similar to the study of Chen et al. (2018), who reported that the F1 fraction accounted for a significantly lower percentage of total concentration of heavy metals. Therefore, these heavy metals exhibited limited migration and transformation ability. Fig. 4 (b) also demonstrates that the proportions of acid soluble fractions of $\mathrm{Ni}, \mathrm{Pb}, \mathrm{Cu}$ and $\mathrm{As}$ were lower or close to $1 \%$, while $\mathrm{Cd}$ acid soluble fraction was $10-20 \%$ at point $\mathrm{Y} 4$. Previous studies have shown that heavy metals with strong mobility have a great influence on environmental quality (Sun et al., 2017). The F4 fraction of $\mathrm{Ni}, \mathrm{Pb}, \mathrm{Cu}$ and As changed only slightly with increasing depth, while the proportion of Cd F4 fraction decreased gradually with increasing depth. In addition, the percentage of the $\mathrm{F} 2$ fraction in $\mathrm{Pb}$ and $\mathrm{Cd}$ accounted for $30-50 \%$, which should be worked on in more and As accounted for $5-15 \%$ and $5-10 \%$, respectively, mainly of the total heavy metal concentrations. The reason might relate to the ore mining activities, as $\mathrm{Cd}$ and $\mathrm{As}$ 
were guest elements in metal ores (Lu et al., 2015). There were little changes in the

F4 fractions of $\mathrm{Ni}, \mathrm{Cu}$ and As with increasing depth, while $\mathrm{Pb}$ and $\mathrm{Cd}$ were gradually increasing. It should be pointed out that the F4 fraction of $\mathrm{Ni}$ was over $90 \%$ at all three points, indicating lower ecological risk. could be due to its limited mobility (Yang et al., 2020). The proportion of various

fractions of $\mathrm{Ni}, \mathrm{Cu}$ and As changed little with depth at all three sampling point, meaning that the fractions of these three elements were less affected by human activities and more influenced by natural factors such as parent materials (Li et al., 2020). points (Y1(a), Y4(b), and Y5(c)).

\subsection{Multivariate statistical analysis}

375 Multivariate statistical analysis included the assessment of correlation coefficients

376 and principal component analysis, which could show the correlation between all

377 factors and how they group together (Ran et al., 2021). The former was mainly used 378 in the present study to reflect the relationship between heavy metals (Cheng et al., 379 2020). A higher value of the correlation coefficient between heavy metals in soil samples indicated one or more common sources of origin of these elements (Guo et 
al., 2012). Fig. 5 shows Pearson's correlation matrix between all heavy metals in the topsoil. A significantly negative correlation $(\mathrm{p}<0.05)$ was detected between Ni and As elements (-0.85), indicating a different source of these two elements. In addition, the correlation coefficients of $\mathrm{Ni}$ with other heavy metals were all negative, e.g. Ni-Pb (-0.18), Ni-Cd (-0.12) and Ni-Cu (-0.27), possibly suggesting a different pathway of $\mathrm{Ni}$ and other elements. Strong correlations $(\mathrm{r}>0.5)$ were found between $\mathrm{Cd}-\mathrm{Pb}$ and $\mathrm{Cd}-\mathrm{Cu}$, reaching values of 0.67 and 0.68 , respectively. The results indicated that the source of origin of these three elements could be the same. As was present in high concentrations and its correlation coefficients with other elements, i.e. As-Ni (-0.85), $\mathrm{As}-\mathrm{Pb}(0.27)$, As-Cd (0.27) and $\mathrm{As}-\mathrm{Cu}(0.08)$ were weak or negative, revealing complex sources of these heavy metals in the topsoil due to human activities (Liu et al., 2021).

Fig. 5. Pearson's correlation matrix between heavy metals in the topsoil at the Wenshan site.

\subsubsection{Principal component analysis (PCA) of heavy metals}

Principal component analysis (PCA) was used to reveal the groups and sources of heavy metals (Li et al., 2018; Wang et al., 2018), which were used to determine the underlying structure of data and latent factors (Cheng et al., 2020). There were two principal components (PCs) present for topsoil heavy metals and the eigenvalue of two components were larger than 1.0 , which accounted for $80.632 \%$ of the total 
variance (Table 2). The component matrix showed that the first principal component (PC1) explained $50.474 \%$ of the total variance, which was closely associated with $\mathrm{Pb}$, $\mathrm{Cd}, \mathrm{Cu}$ and As. PC1 was considered human activities, e.g. mining activities and transport. Zhong et al. (2020) reported that $\mathrm{Cd}$ and As were guest elements in metal ores that could be released in industrial processes. Wu et al. (2021) observed that industrial activities (mining, smelting processes, etc.) had a serious impact on $\mathrm{Cd}$ content in soil. $\mathrm{Pb}$ is an element that can indicate the presence of automobile transport. The cause may be car exhaust fumes formed as a result of the combustion of gasoline and the use of lead-acid batteries (Fang et al., 2021; Huang et al., 2018). Thus, the presence of lead in the ore means that the transportation process contributes to its redistribution. $\mathrm{Cu}$ was also a contributing element to road traffic emissions, which could be attributed to car engine parts and radiators for its corrosion resistance and strength (Fang et al., 2021; Ma et al., 2016). The second principal component (PC2) explained $30.157 \%$ of the total variance related to a higher load of Ni. PC2 could be defined as a natural source, because its values were close to the background concentrations (Wang et al., 2018).

Table 2 Component matrix for heavy metals in the topsoil at the Wenshan site

\subsection{Pollution and risk assessment}

\subsubsection{Ecological risk assessment}

It is necessary to analyze the geographical accumulation of elements to be able to 
assess the degree of heavy metal pollution and potential risks associated with it ( $\mathrm{Li}$ et al., 2017). Geochemical background values (CNEMC, 1990) were used to calculate the $\mathrm{I}_{\text {geo }}$ of topsoil heavy metals, and the results are listed in Table 3 . The order of the Igeo values was as follows: $\mathrm{Cd}>\mathrm{As}>\mathrm{Cu}>\mathrm{Pb}>\mathrm{Ni}$. Of all heavy metals, $\mathrm{Cd}$ was the most serious pollutant reaching a value of 4.31 , i.e. heavy to extremely heavy contamination. Not only $\mathrm{Cd}$, but also As constituted heavy to extremely heavy contamination, and the $I_{\text {geo }}$ value was 4.07 , which also needs more attention. Therefore, the accumulation of $\mathrm{Cd}$ and As in soil can seriously affect the quality of the environment ( $\mathrm{Li}$ et al., 2017). In addition, the degree of $\mathrm{Cu}(1.82)$ and $\mathrm{Pb}(0.18)$ contamination was moderately contaminated and uncontaminated to moderately contaminated, respectively. The $\mathrm{I}_{\text {geo }}$ value of $\mathrm{Ni}$ was -1.44 , representing no contamination.

The $I_{\text {geo }}$ can evaluate the accumulation degree of a single element, but it is not suitable for estimating total pollution. The screening value for soil contamination risk of development land (Table 1, GB36600-2018, MEE, 2018) was applied in the present study to calculate the PI and NIPI. As shown in Table 3, the PI values of topsoil heavy metals were in descending order: $\mathrm{As}>\mathrm{Cd}>\mathrm{Pb}>\mathrm{Ni}>\mathrm{Cu}$. As was the most serious pollutant according to the PI, reaching the value of 25.17 , i.e. more than 7 -fold higher compared to the critical value $(\mathrm{PI}=3)$ of severe pollution. The result must be attributed to the high concentration of As in the process of mining (Fig. 2). As for other heavy metals, the PI values were all less than 0.7 , i.e. representing no pollution. The NIPI is typically used to comprehensively assess the status of heavy metal pollution (Liu et 
al., 2021). The NIPI values at all the sampling points were more than 3 , and the highest value was measured at point Y2 (25.74), followed by Y6 (23.71) (Table 3).

The two points exceeded the critical value more than 8 -fold and 7-fold, respectively, indicating critically severe pollution. The main reason was the high PI value of arsenic in these two samples. The mean value of the NIPI was 18.17 , i.e. more than 6-fold of the critical value, representing severe pollution.

Table 3 Ecological risk assessment of topsoil heavy metal contamination at the Wenshan site

\subsubsection{Health risk assessment}

Han et al. (2021) reported that ingestion, dermal contact and inhalation were the main routes that could have caused damage to human health. The health risk assessment model designed by the US Environmental Protection Agency is commonly applied, because it includes the exposure route and population factors (Han et al., 2018). Table 4 lists the HQ, HI and CR values (mean, max and min) of five heavy metals acting on adults and children through three exposure routes. The $\mathrm{HQ}_{\text {ing }}$ of $\mathrm{Ni}$, $\mathrm{Pb}$ and $\mathrm{Cu}$ contributed more than $96 \%$ in case of adults and $99 \%$ in case of children of the total HQ value. The HQing of As accounted for more than $50 \%$ of the total HQ value for both adults and children. Previous study pointed out that ingestion was the major route causing health risks when exposed to heavy metals (Wang et al., 2021). With respect to the HI, only As posed a significant potential non-carcinogenic risk for 
472 the critical value $(\mathrm{HI}=1)$. Numerous studies have reported that high heavy metal concentrations not only in soil but also in dust could cause adverse effects on the health of the body of local residents (He et al., 2019).

Regarding carcinogenic risks, As was the most serious pollutant with CR values for adults and children of 1.46E-03 and 9.73E-03, i.e. an unacceptable risk (Table 4). In addition, children's exposure to Ni could also cause an unacceptable risk (5.76E-04). The $\mathrm{CR}$ values of $\mathrm{Cd}$ and $\mathrm{Pb}$ for both adults and children, and $\mathrm{Ni}$ for children, were all higher than $1 \times 10^{-6}$ but lower than $1 \times 10^{-4}$, i.e. representing a generally acceptable risk. Table 4 shows that both HI and CR values of all heavy metals for children were higher than for adults, and these results were consistent with the studies of Liu et al. 482 (2021) and Masri et al. (2021). There were two possible reasons, the first was 483 physiological characteristics, e.g. lower tolerance of body organs; the second was the more direct contact, such as "hand-eating" behavior, etc. Overall, As posed a serious carcinogenic and non-carcinogenic risk for adults and children, which should receive more attention. site 


\section{Conclusions}

The present study analyzed the spatial, vertical, and fraction distribution, correlation and principal components of heavy metals in soil, as well as assessed pollution and health risks caused by these metals at the Wenshan mining site. The eastern and south-eastern parts of the site were highly polluted, while the western and north-western parts were less polluted. As pollution in the topsoil was particularly serious, and $\mathrm{Ni}, \mathrm{Cd}$ and $\mathrm{Cu}$ were strongly influenced by external factors. As content in all layers was greater than the standard risk screening value in the three typical profiles. The proportion of different $\mathrm{Ni}, \mathrm{Cu}$ and As fractions changed slightly with depth at all three sampling points, and the share of residual fraction accounted for more than or close to $80 \%$ of the total concentration. In addition, a significant negative correlation $(\mathrm{p}<0.05)$ was detected between $\mathrm{Ni}$ and As, indicating a different source of origin of these two elements. Principal component analysis demonstrated that two PCs, i.e. PC1 identified as human activities, e.g. mining and transport, and PC2 defined as a natural source, both accounted for $80.632 \%$ of the total variance.

The assessment of ecological and health risks showed that the pollution degree of the mining site was critically high, and As was the most influential element. What is more, As also posed a significant potential non-carcinogenic risk and an unacceptable carcinogenic risk for both adults and children. Therefore, a comprehensive understanding of the characteristics of mine pollution and the improvement of emission management in the mining process are essential for the protection of the environment and health of local residents. The present study can provide theoretical 
support and practical foundations for pollution control and prevention.

Authors Contributions: Lei Xu: Resources, Data curation, Formal analysis, Writing original draft; Huiping Dai: Data curation, Formal analysis, Methodology; Lidia Skuza: Validation, Writing - review \& editing; Shuhe Wei: Methodology, Funding acquisition, Project administration, Supervision

Funding: This work was supported by the Special Plan in the Major Research \& Development of the 13rd Five-Year Plan of China (2016YFD0800802), the National Natural Science Foundation of China (31870488), Projects of Shaanxi Province (SLGPT2019KF04-02), and the project of Foreign Experts Bureau of Shaanxi province (G20200241015).

Data availability: The datasets used or analyzed during the current study are available from the corresponding author on reasonable request.

Declarations

Ethical Approval: Not applicable.

Consent to participate: All authors have agreed for authorship, read and approved the manuscript.

530 Consent for publication: All authors have given consent for publishing this study.

531 Competing interests: The authors declare no competing interests.

\section{Reference}

534 Chai, L., Wang, Y., Wang, X., Ma, L., Cheng, Z., Su, L., 2021. Pollution 
characteristics, spatial distributions, and source apportionment of heavy metals in cultivated soil in Lanzhou, China. Ecol. Indic. 125, 107507.

537

Chen, T., Lei, C., Yan, B., Li, L.L., Xu, D.M.,Ying, G.G., 2018. Spatial distribution and environmental implications of heavy metals in typical lead $(\mathrm{Pb})$-zinc $(\mathrm{Zn})$ mine tailings impoundments in Guangdong Province, South China. Environ. Sci. Pollut. Res. 25(36), 36702-36711.

Cheng, W., Lei, S., Bian, Z., Zhao, Y., Li, Y., Gan, Y., 2020. Geographic distribution of heavy metals and identification of their sources in soils near large, open-pit coal mines using positive matrix factorization. J. Hazard. Mater. 387, 121666.

Cui, X., Geng, Y., Sun, R., Xie, M., Feng, X., Li, X., Cui, Z., 2021. Distribution, speciation and ecological risk assessment of heavy metals in Jinan Iron \& Steel Group soils from China. J. Clean Prod. 295, 126504.

Fang, H., Gui, H., Li, J., Yu, H., Wang, M., Jiang, Y., Wang, C., Chen, C., Zhang, Y., Huang, Y. (2021). Risks Assessment Associated with Different Sources of Metals in Abandoned Soil of Zhuxianzhuang Coal Mine, Huaibei Coalfield (Anhui, China). Bull. Environ. Contam. Toxicol. 106(2), 370-376.

Fei, X., Xiao, R., Christakos, G., Langousis, A., Ren, Z., Tian, Y., Lv, X., 2019. Comprehensive assessment and source apportionment of heavy metals in Shanghai agricultural soils with different fertility levels. Ecol. Indic. 106, 105508.

Guan, Y., Zhang, N., Wang, Y., Rong, B., Ju, M., 2020. Comprehensive assessment of soil risk in a de-industrialized area in China. J. Clean Prod. 262, 121302. 
Guo, G., Wu, F., Xie, F., Zhang, R., 2012. Spatial distribution and pollution assessment of heavy metals in urban soils from southwest China. J. Environ. Sci. 24(3), 410-418.

Han, Q., Liu, Y., Feng, X.X., Mao, P., Sun, A., Wang, M., Wang, M.Y., Wang, M.S., 2021. Pollution effect assessment of industrial activities on potentially toxic metal distribution in windowsill dust and surface soil in central China. Sci. Total Environ. 759, 144023.

Han, W., Gao, G., Geng, J., Li, Y., Wang, Y., 2018. Ecological and health risks assessment and spatial distribution of residual heavy metals in the soil of an e-waste circular economy park in Tianjin, China. Chemosphere 197, 325-335.

He, M., Shen, H., Li, Z., Wang, L., Wang, F., Zhao, K., Liu, X., Wendroth, O., Xu, J., 2019. Ten-year regional monitoring of soil-rice grain contamination by heavy metals with implications for target remediation and food safety. Environ. Pollut. $244,431-439$.

Hou, S., Zheng, N., Tang, L., Ji, X., Li, Y., Hua, X., 2019. Pollution characteristics, sources, and health risk assessment of human exposure to $\mathrm{Cu}, \mathrm{Zn}, \mathrm{Cd}$ and $\mathrm{Pb}$ pollution in urban street dust across China between 2009 and 2018. Environ. Int. $128,430-437$.

Huang, J., Guo, S., Zeng, GM., Li, F., Gu, Y., Shi, Y., Shi, L., Liu, W., Peng S, 2018. A new exploration of health risk assessment quantification from sources of soil heavy metals under different land use. Environ. Pollut. 243,49-58

Huang, S., Peng, B., Yang, Z., Chai, L., Xu, Y., Su, C., 2009. Spatial distribution of 
chromium in soils contaminated by chromium-containing slag. Trans. Nonferrous Met. Soc. China 19, 756-764.

581 Huang, T., Deng, Y., Zhang, X., Wu, D., Wang, X., Huang, S., 2021. Distribution, source identification, and health risk assessment of heavy metals in the soil-rice system of a farmland protection area in Hubei Province, Central China. Environ. Sci. Pollut. Res. 1-12.

Jiang, Y., Chao, S., Liu, J., Yang, Y., Chen, Y., Zhang, A., Cao, H., 2017. Source apportionment and health risk assessment of heavy metals in soil for a township in Jiangsu Province, China. Chemosphere 168, 1658-1668.

Kong, F., Chen, Y., Huang, L., Yang, Z., Zhu, K., 2021. Human health risk visualization of potentially toxic elements in farmland soil: A combined method of source and probability. Ecotox. Environ. Safe. 211, 111922.

Li, F.Y., Fan, Z.P., Xiao, P.F., Oh, K., Ma, X.P., Hou, W., 2009. Contamination, chemical speciation and vertical distribution of heavy metals in soils of an old and large industrial zone in Northeast China. Environ. Geol. 57(8), 1815-1823

Li, K., Gu, Y., Li, M., Zhao, L., Ding, J., Lun, Z., Tian, W., 2018. Spatial analysis, source identification and risk assessment of heavy metals in a coal mining area in Henan, Central China. Int. Biodeterior. Biodegrad. 128, 148-154.

Li, S., Wu, J., Huo, Y., Zhao, X., Xue, L., 2020a. Profiling multiple heavy metal contamination and bacterial communities surrounding an iron tailing pond in Northwest China. Sci. Total Environ. 752, 141827.

Li, S.Z., Zhao, B., Jin, M., Hu, L., Zhong, H., He, Z.G., 2020b. A comprehensive 
survey on the horizontal and vertical distribution of heavy metals and microorganisms in soils of a $\mathrm{Pb} / \mathrm{Zn}$ smelter. J. Hazard. Mater. 400, 123255.

Li, X., Yang, H., Zhang, C., Zeng, G., Liu, Y., Xu, W., Wu, Y., Lan, S., 2017. Spatial distribution and transport characteristics of heavy metals around an antimony mine area in central China. Chemosphere 170, 17-24.

Liu, G., Xue, W., Tao, L., Liu, X., Hou, J., Wilton, M., Gao, D., Wang, A., Li, R., 2014. Vertical distribution and mobility of heavy metals in agricultural soils along jishui river affected by mining in Jiangxi province, China. CLEAN-Soil, Air, Water 42, 1450-1456.

Liu, G., Zhou, X., Li, Q., Shi, Y., Guo, G., Zhao, L., Wang, J., Su, Y., Zhang, C., 2020. Spatial distribution prediction of soil As in a large-scale arsenic slag contaminated site based on an integrated model and multi-source environmental data. Environ. Pollut. 267, 115631.

Liu, H.W., Zhang, Y., Yang, J.S., Wang, H.Y., Li, Y.L., Shi, Y., Li, D.C., Holm, P.E., Ou, Q., Hu, W.Y. Hu, W., 2021. Quantitative source apportionment, risk assessment and distribution of heavy metals in agricultural soils from southern Shandong Peninsula of China. Sci. Total Environ. 767, 144879.

Lu, S., Teng, Y., Wang, Y., Wu, J., Wang, J., 2015. Research on the ecological risk of heavy metals in the soil around a $\mathrm{Pb}-\mathrm{Zn}$ mine in the Huize County, China. Acta Geochim. 34 (4), 540-549.

Ma, L., Yang, Z., Li, L., Wang, L., 2016. Source identification and risk assessment of heavy metal contaminations in urban soils of Changsha, a mine-impacted city in 
624

625

626

627

628

629

630

631

632

633

634

635

636

637

638

639

640

641

642

643

644

Masri, S., LeBrón, A.M., Logue, M.D., Valencia, E., Ruiz, A., Reyes, A., Wu, J., 2021. Risk assessment of soil heavy metal contamination at the census tract level in the city of Santa Ana, CA: implications for health and environmental justice. Environ. Sci.-Process Impacts.

MEE, 2018. Ministry of Ecology and Environment, PRC. Soil Environmental Quality-Risk Control Standard for Soil Contamination of Development Land. GB36600-2018 (in Chinese).

Negahban, S., Mokarram, M., Pourghasemi, H. R., Zhang, H., 2021. Ecological risk potential assessment of heavy metal contaminated soils in Ophiolitic formations. Environ. Res. 192, 110305.

Nemerow, N.L., 1974. Scientific Stream Pollution Analysis. McGraw-Hill Book Company, New York.

Niazi, N.K., Bishop, T.F., Singh, B., 201 1. Evaluation of spatial variability of soil arsenic adjacent to a disused cattle-dip site, using model-based geostatistics. Environ. Sci. Technol. 45 (24), 10463-10470.

Ran, H., Guo, Z., Yi, L., Xiao, X., Zhang, L., Hu, Z., Li, C., Zhang, Y., 2021. Pollution characteristics and source identification of soil metal (loid) $\mathrm{s}$ at an abandoned arsenic-containing mine, China. J. Hazard. Mater. 413, 125382.

Stylianou, M., Gavriel, I., Vogiatzakis, I.N., Zorpas, A., Agapiou, A., 2020. Native plants for the remediation in Cyprus: a preliminary assessment. J. Environ. Manag. 274. 
Sun, L., Guo, D., Liu, K., Meng, H., Zheng, Y., Yuan, F., Zhu, G., 2019. Levels, sources, and spatial distribution of heavy metals in soils from a typical coal industrial city of Tangshan, China. Catena 175, 101-109.

Sun, J., Yu, R., Hu, G., Jiang, S., Zhang, Y., Wang, X., 2017. Bioavailability of heavy metals in soil of the Tieguanyin tea garden, southeastern China. Acta Geochim. $36(3), 519-524$

Ure, A.M., Quevauviller, P.H., Muntau, H., Griepink, B., 1993. Speciation of heavy metals in soils and sediments: an account of the improvement and harmonization of extraction techniques undertaken under the auspices of the BCR of the commission of the European communities. Int. J. Environ. Anal. Chem. 51, $135-151$.

USEPA, 1989. Risk Assessment Guidance for Superfund, vol. I. Human Health Evaluation Manual (Part a), Washington, DC. EPA/540/1-89/002.

USEPA, 1997. Exposure Factors Handbook, Final Report. U.S. Environmental Protection Agency, Washington, DC (EPA/600/P-95/002F a-c).

USEPA, 2001. Baseline Human Health Risk Assessment. Vasquez Boulevard and I-70 superfund site Denver, Denver (Co).

Wang, H.Z., Cai, L.M., Wang, Q.S., Hu, G.C., Chen, L.G., 2021. A comprehensive exploration of risk assessment and source quantification of potentially toxic elements in road dust: A case study from a large $\mathrm{Cu}$ smelter in central China. Catena 196, 104930.

Wang, S., Kalkhajeh, Y. K., Qin, Z., Jiao, W., 2020. Spatial distribution and 
assessment of the human health risks of heavy metals in a retired petrochemical industrial area, south China. Environ. Res. 188, 109661.

Wang, Z., Hong, C., Xing, Y., Wang, K., Li, Y., Feng, L., Ma, S., 2018. Spatial distribution and sources of heavy metals in natural pasture soil around copper-molybdenum mine in Northeast China. Ecotox. Environ. Safe. 154, 329-336.

Xiao, L., Guan, D., Chen, Y., Dai, J., Ding, W., Peart, M. R., Zhang, C., 2019. Distribution and availability of heavy metals in soils near electroplating factories. Environ. Sci. Pollut. Res. 26(22), 22596-22610.

Wu, B., Peng, H., Sheng, M., Luo, H., Wang, X., Zhang, R., Xu, F., Xu, H., 2021. Evaluation of phytoremediation potential of native dominant plants and spatial distribution of heavy metals in abandoned mining area in Southwest China. Ecotox. Environ. Safe. 220, 112368.

Xu, L., Dai, H., Skuza, L., Wei, S, 2021. Comprehensive exploration of heavy metal contamination and risk assessment at two common smelter sites. Chemosphere 131350.

Yang, H., Wang, F., Yu, J., Huang, K., Zhang, H., Fu, Z., 2021. An improved weighted index for the assessment of heavy metal pollution in soils in Zhejiang, China. Environ. Res. 192, 110246.

Yang, S., Gu, S., He, M., Tang, X., Ma, L.Q., Xu, J., Liu, X., 2020. Policy adjustment impacts $\mathrm{Cd}, \mathrm{Cu}, \mathrm{Ni}, \mathrm{Pb}$ and $\mathrm{Zn}$ contamination in soils around e-waste area: Concentrations, sources and health risks. Sci. Total Environ. 741, 140442. 
Yu, B., Lu, X.W., Fan, X.Y., Fan, P., Zuo, L., Yang, Y.F., Wang, L., 2021. Analyzing environmental risk, source and spatial distribution of potentially toxic elements in dust of residential area in Xi'an urban area, China. Ecotox. Environ. Safe. 208, 111679.

Zhang, H., Zhang, B.G., Wang, S., Chen, J.L., Jiang, B., Xing, Y., 2020. Spatiotemporal vanadium distribution in soils with microbial community dynamics at vanadium smelting site. Environ. Pollut. 265, 114782.

Zhao, K., Liu, X., Xu, J., Selim, H.M., 2010. Heavy metal contaminations in a soil-rice system: identification of spatial dependence in relation to soil properties of paddy fields. J. Hazard. Mater. 181, 778-787.

Zhong, X., Chen, Z.W., Li, Y.Y., Ding, K.B., Liu, W.S., Liu, Y., Yuan, Y.Q., Zhang, M.Y., Baker, Alan J.M., Yang, W.J. Fei, Y.H. Wang, Y.J. Chao, Y.Q., Qiu, R.L., 2020. Factors influencing heavy metal availability and risk assessment of soils at typical metal mines in Eastern China. J. Hazard. Mater. 400, 123289. 


\section{Table captions}

721 Table 1 Heavy metal concentrations in the topsoil at the Wenshan site

722 Table 2 Component matrix for heavy metals in the topsoil at the Wenshan site

723 Table 3 Ecological risk assessment of topsoil heavy metal contamination at the

724 Wenshan site

725 Table 4 Assessment of health risk posed by heavy metals in the topsoil at the Wenshan 726 site

\section{Figure captions}

729

730

731

732

733

734

735

736

737

738

739

740

741

Fig. 1. Geographic information concerning the mining site, including sampling locations and cases.

Fig. 2. Spatial maps showing the distribution of heavy metals in the topsoil at the Wenzhou mining site.

Fig. 3. Vertical distribution of soil heavy metal concentrations at different sampling points (Y1(a), Y4(b) and Y5(c),).

Fig. 4. Fraction distribution of heavy metals in soil with depth at different sampling points (Y1(a), Y4(b), and Y5(c)).

Fig. 5. Pearson's correlation matrix between heavy metals in the topsoil at the Wenshan site. 
743 Table 1 Heavy metal concentrations in the topsoil at the Wenshan site

\begin{tabular}{llllll}
\hline & $\begin{array}{l}\mathrm{Ni} \\
\left(\mathrm{mg} \mathrm{kg}^{-1}\right)\end{array}$ & $\begin{array}{l}\mathrm{Pb} \\
\left(\mathrm{mg} \mathrm{kg}^{-1}\right)\end{array}$ & $\begin{array}{l}\mathrm{Cd} \\
\left(\mathrm{mg} \mathrm{kg}^{-1}\right)\end{array}$ & $\begin{array}{l}\mathrm{Cu} \\
\left(\mathrm{mg} \mathrm{kg}^{-1}\right)\end{array}$ & $\begin{array}{l}\mathrm{As} \\
\left(\mathrm{mg} \mathrm{kg}^{-1}\right)\end{array}$ \\
\hline Mean & 26.26 & 70.45 & 7.04 & 292.24 & 503.31 \\
Median & 20.34 & 65.06 & 6.03 & 193.88 & 514.32 \\
Min & 15.25 & 54.36 & 3.77 & 123.43 & 182.9 \\
Max & 56.83 & 97.15 & 13.13 & 625.31 & 713.36 \\
SD & 14.19 & 14.18 & 3.09 & 181.40 & 171.88 \\
CV (\%) & 54.03 & 20.13 & 43.86 & 62.07 & 34.15 \\
Risk screening value & 150 & 400 & 20 & 2000 & 20 \\
(GB36600-2018) & & & & & \\
Risk intervention & 600 & 800 & 47 & 8000 & 120 \\
value & & & & & \\
(GB36600-2018) & & & & & \\
\hline
\end{tabular}


771 Table 2 Component matrix for heavy metals in the topsoil at the Wenshan site

\begin{tabular}{lll}
\hline Heavy Metal & PC1 & PC2 \\
\hline $\mathrm{Ni}$ & -0.640 & 0.714 \\
$\mathrm{~Pb}$ & 0.733 & 0.336 \\
$\mathrm{Cd}$ & 0.800 & 0.475 \\
$\mathrm{Cu}$ & 0.703 & 0.419 \\
$\mathrm{As}$ & 0.665 & -0.696 \\
Eigenvalue & 2.524 & 1.508 \\
Cumulative of variation (\%) & 50.474 & 80.631 \\
\hline
\end{tabular}

772 Extraction method: Principal component analysis

773

774

775

776

777

778

779

780

781

782

783

784

785

786

787

788

789

790

791

792

793

794

795

796

797

798

799

800

801

802

803 
Table 3 Ecological risk assessment of topsoil heavy metal contamination at the Wenshan site

\begin{tabular}{|c|c|c|c|c|c|c|c|c|c|c|c|}
\hline \multirow[b]{2}{*}{ Site } & \multicolumn{5}{|l|}{$\underline{I_{\text {geo }}}$} & \multicolumn{5}{|l|}{ PI } & \multirow[t]{2}{*}{ NIPI } \\
\hline & $\mathrm{Cu}$ & $\mathrm{Ni}$ & $\mathrm{Pb}$ & $\mathrm{Cd}$ & As & $\overline{\mathrm{Cu}}$ & $\mathrm{Ni}$ & $\mathrm{Pb}$ & $\mathrm{Cd}$ & As & \\
\hline $\mathrm{Y} 1$ & 1.49 & -2.01 & 0.39 & 3.53 & 4.32 & 0.10 & 0.11 & 0.20 & 0.19 & 27.51 & 19.85 \\
\hline Y2 & 0.83 & -1.85 & -0.16 & 3.90 & 4.69 & 0.06 & 0.12 & 0.14 & 0.24 & 35.67 & 25.74 \\
\hline Y3 & 3.17 & -1.88 & 0.12 & 4.69 & 4.12 & 0.31 & 0.12 & 0.17 & 0.42 & 23.93 & 17.28 \\
\hline Y4 & 1.30 & -1.25 & 0.01 & 4.35 & 3.99 & 0.09 & 0.18 & 0.15 & 0.33 & 21.92 & 15.83 \\
\hline Y5 & 1.47 & -0.17 & 0.07 & 4.04 & 2.73 & 0.010 & 0.38 & 0.16 & 0.27 & 9.15 & 6.62 \\
\hline Y6 & 2.68 & -1.47 & 0.67 & 5.33 & 4.57 & 0.22 & 0.15 & 0.24 & 0.66 & 32.82 & 23.71 \\
\hline Mean & 1.82 & -1.44 & 0.18 & 4.31 & 4.07 & 0.15 & 0.18 & 0.18 & 0.35 & 25.17 & 18.17 \\
\hline
\end{tabular}


Table 4 Assessment of health risk posed by heavy metals in the topsoil at the Wenshan site

\begin{tabular}{|c|c|c|c|c|c|c|c|c|c|c|c|}
\hline \multirow[t]{2}{*}{ Elements } & & \multicolumn{2}{|l|}{$\mathrm{HQ}_{\text {ing }}$} & \multicolumn{2}{|l|}{$\mathrm{HQ}_{\text {derm }}$} & \multicolumn{2}{|l|}{$\mathrm{HQ}_{\text {inh }}$} & \multicolumn{2}{|l|}{$\mathrm{HI}$} & \multicolumn{2}{|l|}{$\mathrm{CR}$} \\
\hline & & Adults & Children & Adults & Children & Adults & Children & Adults & Children & Adults & Children \\
\hline \multirow[t]{3}{*}{$\mathrm{Cd}$} & mean & $1.19 \mathrm{E}-02$ & $8.50 \mathrm{E}-02$ & $5.42 \mathrm{E}-03$ & $9.52 \mathrm{E}-03$ & $5.41 \mathrm{E}-02$ & $1.93 \mathrm{E}-01$ & $7.15 \mathrm{E}-02$ & $2.88 \mathrm{E}-01$ & $9.75 \mathrm{E}-07$ & $3.48 \mathrm{E}-06$ \\
\hline & $\max$ & $2.22 \mathrm{E}-02$ & $1.58 \mathrm{E}-01$ & $1.01 \mathrm{E}-02$ & $1.77 \mathrm{E}-02$ & $1.01 \mathrm{E}-01$ & $3.61 \mathrm{E}-01$ & $1.33 \mathrm{E}-01$ & $5.37 \mathrm{E}-01$ & $1.82 \mathrm{E}-06$ & $6.50 \mathrm{E}-06$ \\
\hline & $\min$ & $6.36 \mathrm{E}-03$ & $4.55 \mathrm{E}-02$ & $2.90 \mathrm{E}-03$ & $5.09 \mathrm{E}-03$ & $2.90 \mathrm{E}-02$ & $1.03 \mathrm{E}-01$ & $3.82 \mathrm{E}-02$ & $1.54 \mathrm{E}-01$ & $5.22 \mathrm{E}-07$ & $1.86 \mathrm{E}-06$ \\
\hline \multirow[t]{3}{*}{ As } & mean & $2.83 \mathrm{E}+00$ & $2.02 \mathrm{E}+01$ & $7.88 \mathrm{E}-02$ & $1.38 \mathrm{E}-01$ & $2.58 \mathrm{E}+00$ & $9.21 \mathrm{E}+00$ & $5.49 \mathrm{E}+00$ & $2.96 \mathrm{E}+01$ & $1.46 \mathrm{E}-03$ & $9.73 \mathrm{E}-03$ \\
\hline & $\max$ & $4.01 \mathrm{E}+00$ & $2.87 \mathrm{E}+01$ & $1.12 \mathrm{E}-01$ & $1.96 \mathrm{E}-01$ & $3.66 \mathrm{E}+00$ & $1.31 \mathrm{E}+01$ & $7.78 \mathrm{E}+00$ & $4.19 \mathrm{E}+01$ & $2.06 \mathrm{E}-03$ & $1.38 \mathrm{E}-02$ \\
\hline & $\min$ & $1.03 \mathrm{E}+00$ & $7.35 \mathrm{E}+00$ & $2.86 \mathrm{E}-02$ & $5.02 \mathrm{E}-02$ & 9.37E-01 & $3.35 \mathrm{E}+00$ & $1.99 \mathrm{E}+00$ & $1.08 \mathrm{E}+01$ & $5.29 \mathrm{E}-04$ & $3.54 \mathrm{E}-03$ \\
\hline \multirow[t]{3}{*}{$\mathrm{Ni}$} & mean & $2.22 \mathrm{E}-03$ & $1.58 \mathrm{E}-02$ & $9.36 \mathrm{E}-05$ & $1.64 \mathrm{E}-04$ & & & $2.31 \mathrm{E}-03$ & $1.60 \mathrm{E}-02$ & $9.69 \mathrm{E}-05$ & $5.76 \mathrm{E}-04$ \\
\hline & $\max$ & $4.80 \mathrm{E}-03$ & $3.43 \mathrm{E}-02$ & $2.03 \mathrm{E}-04$ & $3.55 \mathrm{E}-04$ & & & $5.00 \mathrm{E}-03$ & $3.46 \mathrm{E}-02$ & $2.10 \mathrm{E}-04$ & $1.25 \mathrm{E}-03$ \\
\hline & $\min$ & $1.33 \mathrm{E}-03$ & $9.54 \mathrm{E}-03$ & $5.64 \mathrm{E}-05$ & $9.89 \mathrm{E}-05$ & & & $1.39 \mathrm{E}-03$ & $9.64 \mathrm{E}-03$ & $5.86 \mathrm{E}-05$ & $3.47 \mathrm{E}-04$ \\
\hline \multirow[t]{3}{*}{$\mathrm{Pb}$} & mean & $8.50 \mathrm{E}-02$ & $6.07 \mathrm{E}-01$ & $2.59 \mathrm{E}-03$ & $4.54 \mathrm{E}-03$ & & & $8.75 \mathrm{E}-02$ & $6.12 \mathrm{E}-01$ & $1.08 \mathrm{E}-06$ & $7.46 \mathrm{E}-06$ \\
\hline & $\max$ & $1.17 \mathrm{E}-01$ & 8.37E-01 & $3.57 \mathrm{E}-03$ & $6.26 \mathrm{E}-03$ & & & $1.21 \mathrm{E}-01$ & $8.43 \mathrm{E}-01$ & $1.48 \mathrm{E}-06$ & $1.03 \mathrm{E}-05$ \\
\hline & $\min$ & $6.56 \mathrm{E}-02$ & 4.68E-01 & $2.00 \mathrm{E}-03$ & $3.50 \mathrm{E}-03$ & & & $6.76 \mathrm{E}-02$ & 4.72E-01 & $8.30 \mathrm{E}-07$ & 5.75E-06 \\
\hline \multirow[t]{3}{*}{$\mathrm{Cu}$} & mean & $1.23 \mathrm{E}-02$ & $8.81 \mathrm{E}-02$ & $4.69 \mathrm{E}-04$ & $8.22 \mathrm{E}-04$ & & & $1.28 \mathrm{E}-02$ & $8.89 \mathrm{E}-02$ & & \\
\hline & $\max$ & $2.64 \mathrm{E}-02$ & $1.89 \mathrm{E}-01$ & $1.00 \mathrm{E}-03$ & $1.76 \mathrm{E}-03$ & & & $2.74 \mathrm{E}-02$ & $1.90 \mathrm{E}-01$ & & \\
\hline & $\min$ & $5.21 \mathrm{E}-03$ & $3.72 \mathrm{E}-02$ & $1.98 \mathrm{E}-04$ & $3.47 \mathrm{E}-04$ & & & $5.41 \mathrm{E}-03$ & $3.76 \mathrm{E}-02$ & & \\
\hline
\end{tabular}




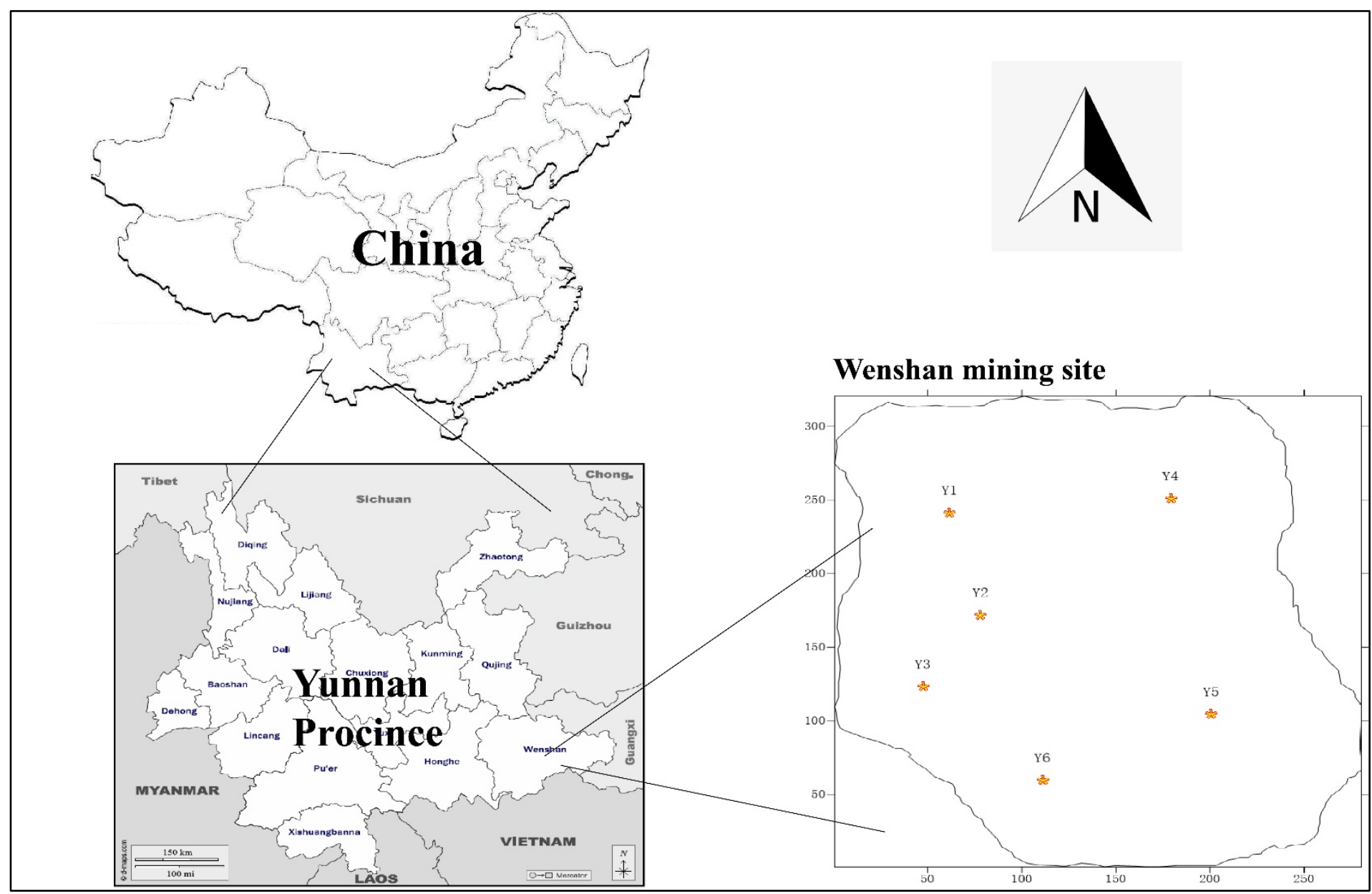

Fig. 1. Geographic information concerning the mining site, including sampling locations and cases. 

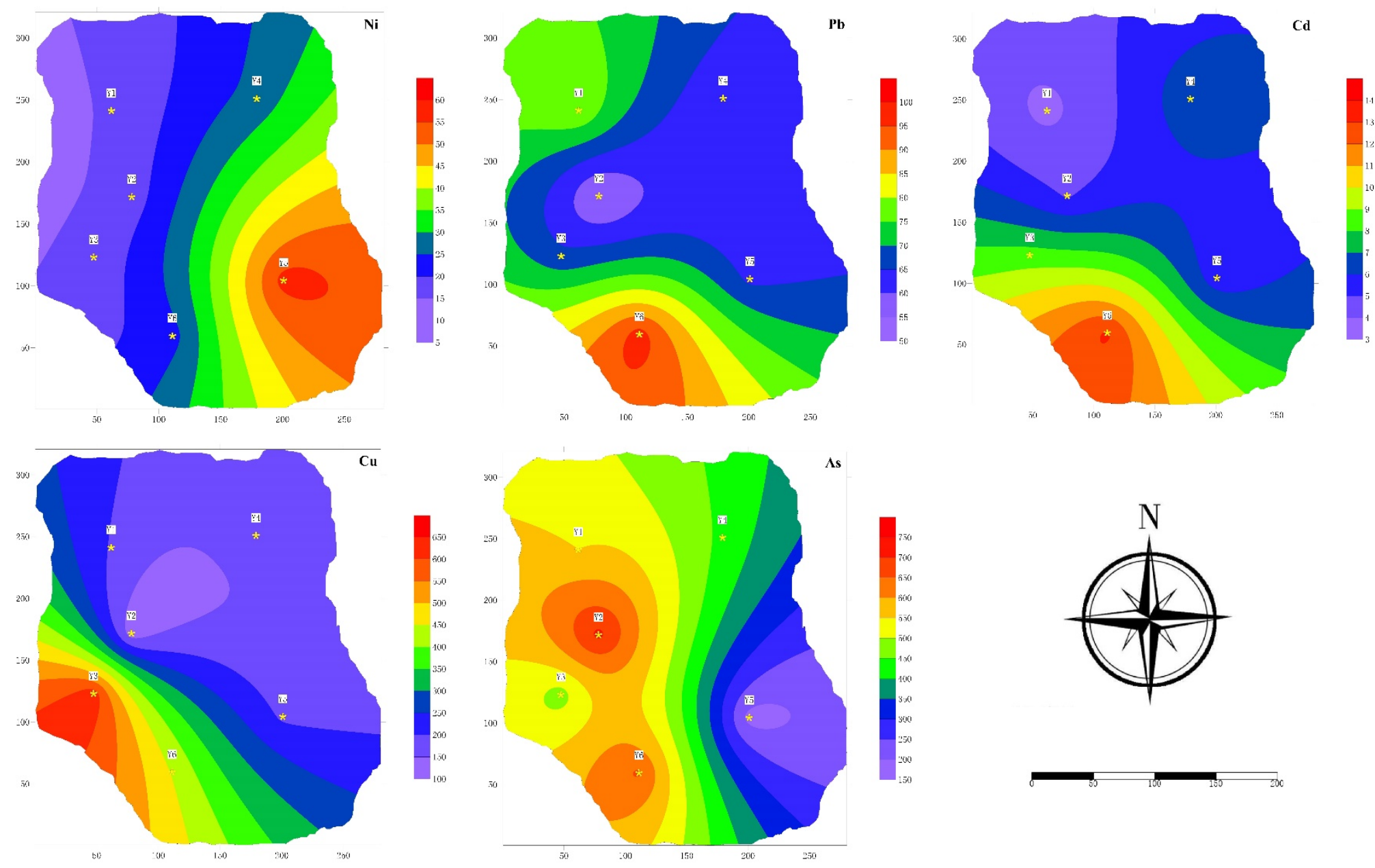

Fig. 2. Spatial maps showing the distribution of heavy metals in the topsoil at the Wenshan site. 


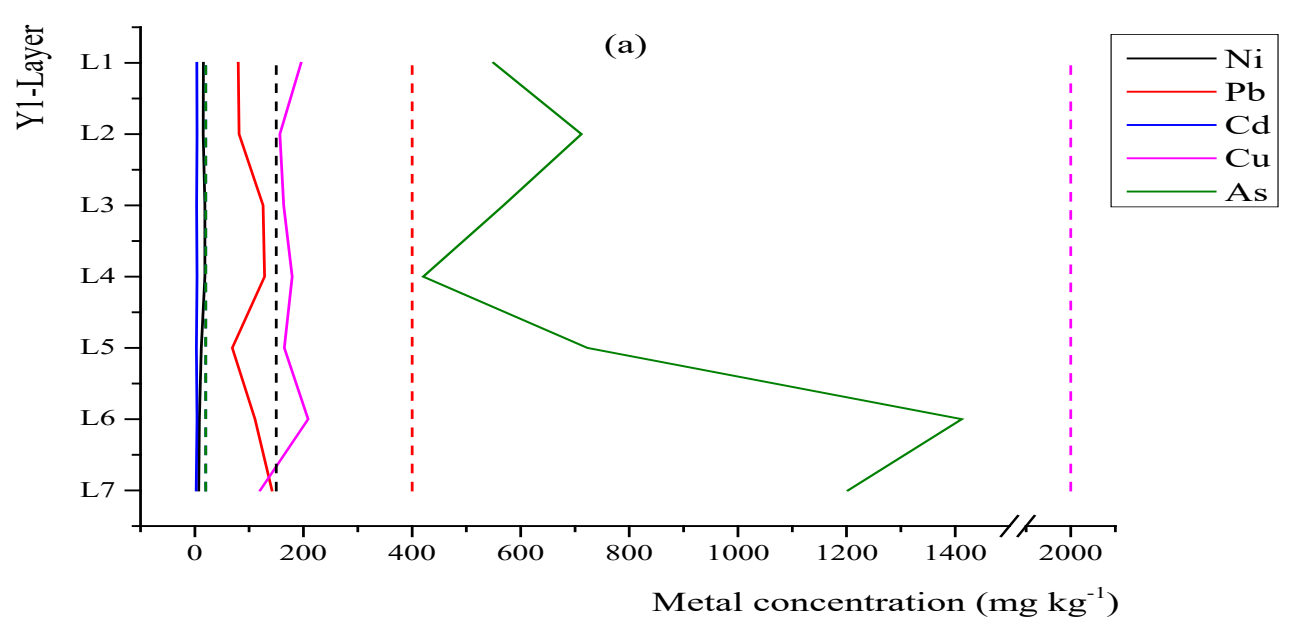

1

Metal concentration $\left(\mathrm{mg} \mathrm{kg}^{-1}\right)$
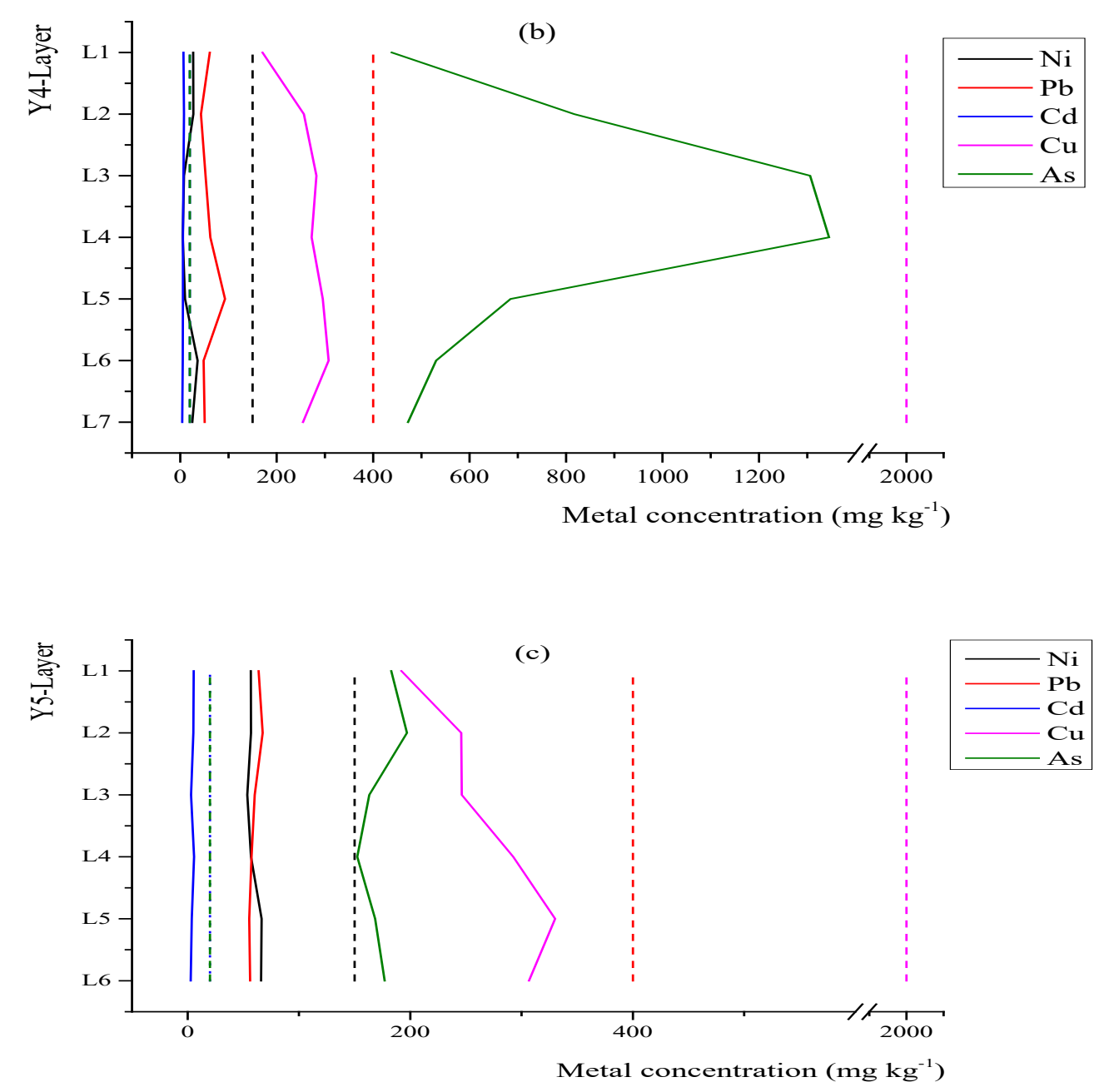

4 Fig. 3. Vertical distribution of soil heavy metal concentrations at different sampling points (Y1(a),

5 Y4(b) and Y5(c),). The solid line represents the concentration change of heavy metal with depth,

6 and the dotted line represents the risk screening value of the standard (GB36600-2018, MEE, 7 2018). 
(a)

Acid soluble $\square$ Reducible $\square$ Oxidizable $\square$ Residual
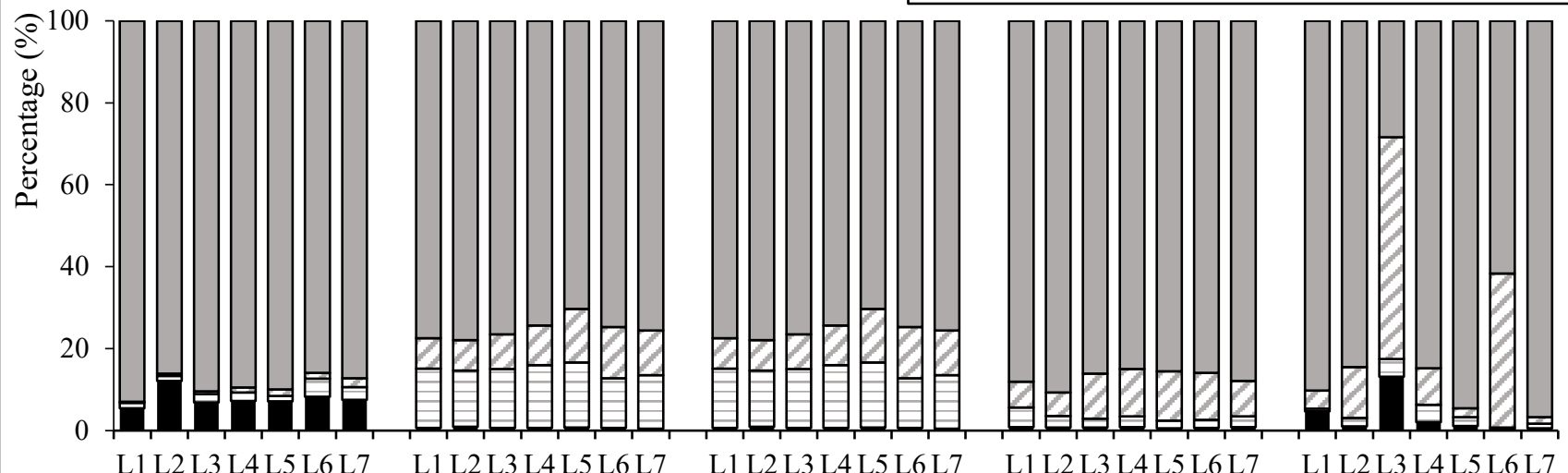

$\mathrm{Ni}$

$\mathrm{Pb}$

$\mathrm{Cd}$

$\mathrm{Cu}$

As Layer

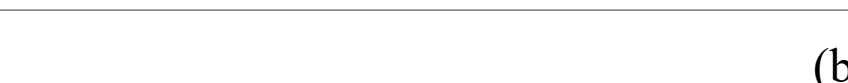

(b)
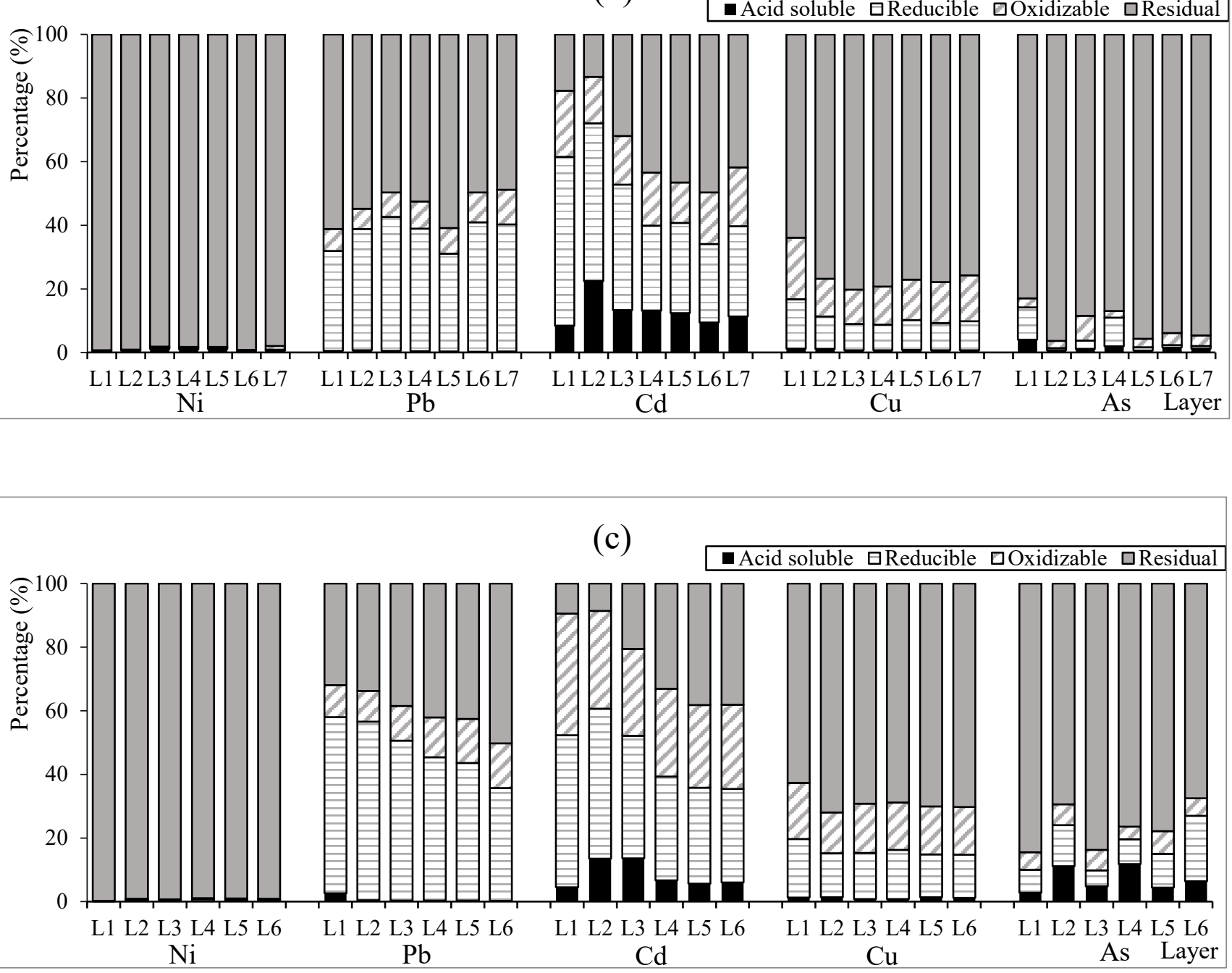

13 Fig. 4. Fraction distribution of heavy metals in soil with depth at different sampling points (Y1(a),

14 Y4(b), and Y5(c)). 


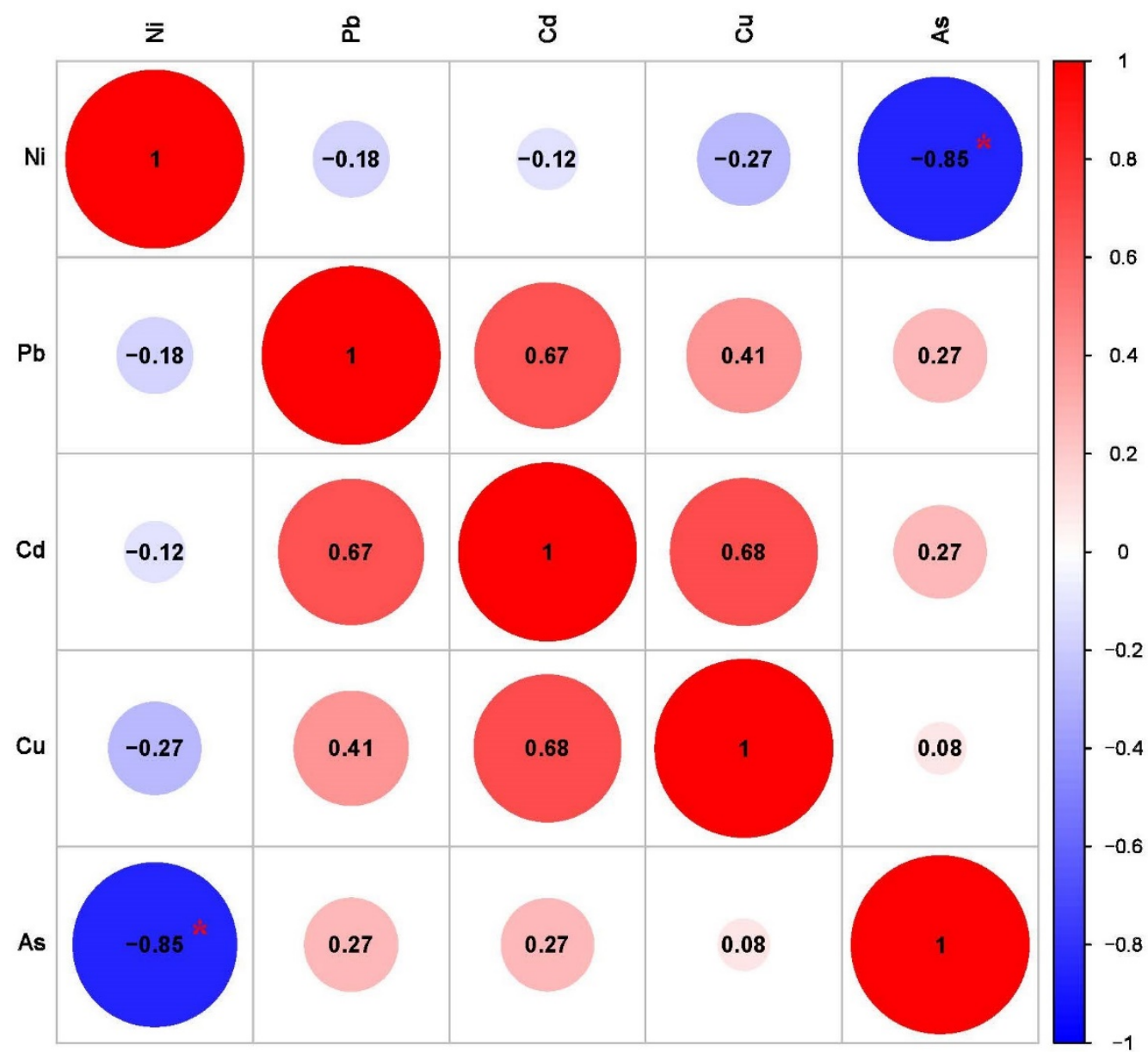

Fig. 5. Pearson's correlation matrix between heavy metals in the topsoil at the Wenshan site. (* 20 represents the correlation coefficients significant at $\mathrm{p}<0.05$. The circle size is relevant to the 21 correlation coefficient value and color shows the positive correlation (red) or negative correlation 22 (blue)). 


\section{Supplementary Files}

This is a list of supplementary files associated with this preprint. Click to download.

- Conflictof Interest.docx

- GraphicalAbstract.pdf

- Highlights.docx 